\title{
PROFESSIONAL TRAINING OF FUTURE ELEMENTARY SCHOOL TEACHERS FOR THE ORGANIZATION OF DISTANCE LEARNING IN THE CONDITIONS OF A MODERN EDUCATIONAL LANDSCAPE
}

\section{ПІДГОТОВКА МАЙБУТНІХ УЧИТЕЛІВ ПОЧАТКОВОЇ ШКОЛИ ДО ОРГАНІЗАЦІЇ ДИСТАНЦІЙНОГО НАВЧАННЯ В УМОВАХ СУЧАСНОГО ОСВІТНЬОГО ЛАНДШАФТУ}

\author{
Maryna NESTERENKO, \\ Candidate of Pedagogical Sciences \\ Марина НЕСТEPEHКО, \\ nesterenko marina1988@ukr.net \\ https://orcid.org/0000-0003-3005-5910 \\ Berdiansk State Pedagogical \\ University \\ 4, Schmidta St., Berdiansk, \\ Zaporizhzhia region, 71100 \\ Original manuscript received: December 03, 2021 \\ Revised manuscript accepted: December 20, 2021
}

\begin{abstract}
The article analyzes the reasons and results of the first experience of mass work of Ukrainian educational institutions in the remote mode, which showed that in general it was possible to change and adapt them for full functioning. The prospects for the development of distance learning technologies have been determined that provide people with access to education without restrictions on age, gender, social status, health status and in emergencies, which increases the mobility of society.

It was revealed that the problem of professional training of future teachers for the organization of the distance educational process in primary school requires special attention, since children of primary school age are characterized by a low level of independence in organizing their own educational and cognitive activities, a weak arbitrariness of attention, and a high need for personal contact with a teacher. This determines the special specifics of the teacher's activities.

A summary is presented and the effectiveness of the selective course "Distance education in primary school» aimed at the formation of professional competence of future teachers, in particular its component, ensuring the readiness to implement the educational process in primary school in the format of distance learning or blended learning, is experimentally proved. Students have the opportunity to explore the essence of distance learning in primary school; understand the specifics of communication between teachers and students, parents, administration during distance learning, work with children with special educational needs in such conditions; to study methodical recommendations on the organization of online classes; define technical, ergonomic and ethical criteria for quality video conferencing; to master the experience of working with various services for the organization of video communication; master the general principles of organizing the distance learning process with the help of Google Classroom; to get acquainted with high-quality Ukrainian-language video resources for visualization of educational material of the lesson, services for conducting online testing of students, conveniences of interactive online boards.
\end{abstract}


Key words: training of future primary school teachers, distance educational process in primary school, digitalization of society, digital pedagogy, technologies for distance learning, selective discipline.

Вступ. Усеохоплююча цифровізація - один із головних факторів зростання світової економіки в найближчі 5-10 років. Це передбачає впровадження цифрових технологій у всі сфери життя людства, перехід біологічних і фрізичних систем у кібербіологічні та кіберфізичні (об'єднання фрізичних і обчислювальних компонентів), переміщення діяльності з реального світу у віртуальний (Вишневський, Гаркушенко, Князєв, Липницький, Чекіна, 2020), (Цифрова адженда України, 2016). Пандемія COVID-19 суттєво інтенсифрікувала цей процес і зумовила значні зміни - перехід соціально-інтерактивної інституції формальної освіти в цифрову площину.

Рефлексія педагогічного досвіду під час екстреного запровадження дистанційного навчання в 2020 році (Дистанційне навчання: виклики, результати та перспективи, 2020) актуалізує вирішення проблем педагогічного, методичного й організаційного характеру, зокрема йдеться про системну підготовку майбутніх учителів, у тому числі й для початкової школи, до якісної реалізації освітнього процесу в дистанційному фрорматі.

Об'єктивним є той фракт, що поширення дистанційної фрорми навчання - невідворотній процес, пов'язаний із розвитком цифрового суспільства. Доказом цього $€$ висновки досліджень, проведених В. Биковим, Т. Близнюк, В. Кухаренком, Н. Морзе, О. Саган, О. Співаковським, О. Струтинською, М. Умрик та іншими вченими.

Так, у роботах В. Бикова, М. Лещенка, О. Саган та інших схарактеризовано поняття, які пояснюють унікальність сучасного освітнього ландшафту: цифрова педагогіка (наука про закономірності створення позитивної інтегрованої педагогічної реальності при конвергенції фізичного та віртуального) (Биков, Лещенко, 2016) i цифрова дидактика як розділ педагогіки, що вивчає принципи, методи, засоби та організаційні форми навчання в умовах цифрового освітнього середовища (Sagan, Nahrybelniy, Nahrybeina, Fediaieva, Liba, Kabelnikova, 2020).

Ученими О. Співаковським, Л. Петуховою та ін. досліджено специфріку сучасної трисуб'єктної взаємодії на прикладі закладу вищої освіти: викладач, здобувач та інформаційно-комунікаційне педагогічне середовище, в якому останнє створює оптимальні умови для реалізації потенціалу та здібностей майбутнього вчителя, підвищення його мотивації та розвитку індивідуальності (Спиваковский, Петухова, Кравцов, Воропай, Коткова, 2016).

На думку О. Струтинської та М. Умрик, така трансфрормація відкриває широкі перспективи для підвищення ефективності освітнього процесу, метою якого стає формування наскрізних навичок і цифрової компетентності особистості, оскільки ключовим ресурсом суспільства є громадяни, які вміють 
ефективно та продуктивно використовувати інформаційні технології для власних потреб, а також для досягнення спільних економічних, суспільних і громадських цілей (Струтинська, Умрик, 2020).

Дистанційне навчання за своєю суттю $є$ фрормою реалізації освітнього процесу. Однак Т. Близнюк, О. Будник та Т. Качак надають йому більш широкого значення та вважають певною соціальною технологією, яка сприяє забезпеченню конституційного права доступу людей до освіти без обмежень за віком, статтю, соціальним статусом, станом здоров'я та в умовах надзвичайних ситуацій (зокрема пандемії), що підвищує мобільність населення (Blyznyuk, Budnyk, Kachak, 2021).

Специфіку організації дистанційного навчання в початковій школі, особливості використання цифрових інструментів у педагогічній діяльності досліджували вчені, які займаються проблемою професійної підготовки учителів цього профілю: О. Буднік, Л. Коваль, О. Муковіз, О. Овчарук, Л. Петухова та ін.

Так, ключовою перевагою дистанційного навчання, як вважає Л. Коваль, є можливість планування та реалізації індивідуальної освітньої траєкторії кожного здобувача освіти залежно від власних можливостей та потреб, що є характерним для концепції розвитку особистості. Важливим фактором у цьому напрямку $є$ формування умінь самостійно розвивати навички когнітивної діяльності з використанням сучасних і перспективних засобів інформаційних технологій (Коваль, 2021).

При цьому, як зазначає О. Будник, більшість майбутніх учителів $є$ прогресивно налаштованими стосовно використання цифрових ресурсів та інструментів в освітньому процесі початкової школи, тому вважають необхідним підвищення рівня своєї цифрової грамотності для налагодження комунікації, співпраці та організації діяльності з учнями онлайн, застосування сучасних програмних засобів для візуалізації даних, використання ресурсів для створення, обміну та поширення контенту; безпечної роботи в мережі Інтернет; використання ІКТ для оцінювання тощо (Будник, 2020).

Виділення невирішених раніше частин загальної проблеми. Масове переведення закладів формальної освіти в дистанційний і змішаний формат навчання через пандемію змусило суттєво змінити й адаптувати їх середовище. Педагоги з різним рівнем успіху намагаються забезпечити повноцінне функціонування усіх структурних компонентів освітнього процесу: віртуальні класи, особисті кабінети, онлайн-уроки, дистанційне цифрове середовище та ін. Ми вважаємо, що для початкової школи означена проблема стала надзвичайно гостро, оскільки для дітей цього віку характерним $є$ низький рівень самостійності в організації власної навчально-пізнавальної діяльності, слабка довільність уваги, висока потреба в особистому контакті 3 учителем (Nesterenko, 2020). Крім того, технічні можливості суттєво розширили творчий потенціал педагогів, але все це відбувається безсистемно, ґрунтуючись на їх особистому ентузіазмі (Кухаренко, Бондаренко, 2020). 
Ураховуючи всі переваги цифровізації освіти та темпи вдосконалення технологій реалізації дистанційної форми навчання, відчутним є брак спеціальних досліджень, спрямованих на підготовку майбутніх учителів початкової школи до реалізації якісного освітнього процесу за таких умов.

Метою статті є презентація змісту авторської дисципліни вибіркового циклу «Дистанційна освіта в початковій школі» та результатів ії ефективності для забезпечення підготовки майбутніх учителів до організації дистанційного освітнього процесу в початковій школі.

Методи та методики дослідження. Під час роботи використано комплекс таких методів: теоретичні (аналіз наукової літератури з метою з'ясування стану та перспектив досліджуваної проблеми; синтез, узагальнення, порівняння, абстрагування й конкретизація - для усвідомлення сутності та структури процесу професійної підготовки майбутніх учителів до організації дистанційного освітнього процесу в початковій школі) й емпіричні (анкетування, бесіда - для визначення рівнів готовності до організації дистанційного освітнього процесу в початковій школі; педагогічний експеримент - для перевірки ефективності змісту запропонованої дисципліни; статистичні методи - для кількісного та якісного аналізу результатів педагогічного експерименту).

Результати та дискусії. У 2020/2021 навчальному році в Бердянському державному педагогічному університеті було проведено експериментальну роботу, в якій взяло участь 78 здобувачів вищої освіти 4 курсу освітньо-професійної програми «Початкова освіта» (18 осіб денної та 60 осіб заочної форми навчання), які вибрали вибірковий освітній компонент «Дистанційна освіта в початковій школі». Він спрямований на формування професійної компетентності майбутніх педагогів, зокрема її складової, яка забезпечує готовність до реалізації освітнього процесу в початковій школі у форматі дистанційного або змішаного навчання. Контрольну групу склали 92 здобувачі вищої освіти 2 курсу зі скороченим терміном навчання освітньо-професійної програми «Початкова освіта» (19 осіб денної та 73 заочної фрорми навчання).

Основними завданнями вивчення означеної дисципліни є: оволодіння студентами системою теоретичних знань щодо сутності й особливостей дистанційного та змішаного навчання; фрормування практичних умінь, необхідних для організації дистанційного та змішаного навчання в початковій школі; накопичення досвіду використання цифрових технологій для урізноманітнення освітнього процесу тощо. Обсяг курсу становить 90 годин (3 кредити ЕСТS, 6 модулів).

Зміст першого модуля спрямовано на опанування двох тем. У ході вивчення теми «Сучасні тенденції розвитку освіти» здобувачі мають можливість дослідити генезу проблеми появи дистанційного формату навчання, а саме проаналізувати актуальні освітні тренди (макро-, мезо- та мікромасштабу) та визначити характерні особливості формальної, неформальної та інформальної освіти. Важливою складовою роботи над темою $є$ практичне дослідження особливостей 
(порівняння) форм і методів організації формальної та неформальної освіти, а також формування в студентів навичок пошуку онлайн платформ, які надають послуги з неформальної педагогічної освіти; стимулювання до професійного самовдосконалення шляхом складання програми професійного розвитку 3 урахуванням можливостей формальної, неформальної та інформальної освіти. Другу тему «Дистанційне та змішане навчання в початковій школі» присвячено розгляду сутності дистанційної форми навчання в початковій школі, а саме: іï переваги та недоліки, стратегія дій закладу освіти для врегулювання організаційних моментів під час запровадження дистанційного навчання, зона відповідальності вчителів у цьому питанні, санітарно-гігієнічні вимоги до тривалості онлайн уроків у початковій школі, відмінності дистанційної та змішаної форм навчання. Практичне заняття передбачає формування в здобувачів вищої освіти організаторських навичок реалізації технології дистанційного навчання в початковій школі та апробацію різних моделей змішаного навчання.

Робота над модулем «Особливості освітнього процесу в початковій школі в умовах дистанційного навчання» передбачає розкриття деталей векторів комунікації вчителя 3 учнями, адміністрацією під час дистанційного навчання, висвітлення специфіки роботи з дітьми з особливими освітніми потребами в таких умовах, ознайомлення з методами заохочення здобувачів початкової освіти до академічної доброчесності та підтримки їх уваги під час онлайн занять. Важливо не тільки презентувати студентам можливі труднощі, а й стимулювати їх до розробки власних правил комунікації в майбутньому класі, моделювання діяльності по залученню дітей 3 гіперактивністю/розладом аутичного спектру/синдромом Дауна до освітньої діяльності засобами дистанційних технологій.

Опрацювання матеріалів модуля «Технології організації синхронної освітньої діяльності в початковій школі» потребує вивчення методичних рекомендацій з організації онлайн занять, визначення технічних, ергономічних та етичних критеріїв якісної відеоконференції, проведення практикуму роботи з різними сервісами для організації відеозв'язку (Zoom, Skype, Google Meet, Viber та ін.), їх порівняння. Слід приділити особливу увагу питанню, чи можна учневі записувати онлайн урок із вчителем. Передбачається організація дискусії серед здобувачів вищої освіти, аналіз нормативних документів, які регулюють означену проблему.

Заплановано також роботу над модулем «Goggle Clasroom як універсальна платформа для системної взаємодії вчителя зі здобувачами під час дистанційного освітнього процесу в початковій школі». У ньому розкрито загальні принципи організації дистанційного освітнього процесу за допомогою означеного сервісу та методику системної роботи з ним. Студенти відпрацьовують алгоритми створення курсу, додавання учасників, розміщення, призначення, перевірки й оцінювання завдань у Goggle Clasroom, ведення електронного журналу. 
Модуль «Технології організації асинхронної взаємодії учасників освітнього процесу в початковій школі» спрямовано на ознайомлення здобувачів вищої освіти з якісними україномовними відеоресурсами для візуалізації навчального матеріалу уроку, сервісами для проведення онлайн тестувань учнів, можливостями інтерактивних онлайн дошок. На практичному занятті з теми студентам важливо набути досвіду моделювання діяльності вчителя початкової школи зі створення уроків 3 навчальним контентом вивчених ресурсів.

Модуль «Проблеми дистанційної освіти в Україні та шляхи їх подолання» розкриває сутність таких важливих питань, як комунікація 3 батьками під час дистанційного навчання, здоров'язбережувальний режим роботи та оцінювання досягнень здобувачів початкової освіти. Як результат, студенти мають оволодіти базовими навичками таймменеджменту для організації безпечного режиму своєї роботи та досвідом контрольно-оцінювальної діяльності.

Варто зазначити, що програмою курсу передбачено максимальний практико-орієнтований зміст завдань для самостійної роботи. Їх розроблено для розвитку навичок роботи здобувачів вищої освіти 3 різними цифровими ресурсами, які є корисними в дистанційній роботі вчителя початкової школи: групова діяльність над хмарними документами Google, створення інтерактивних опитувальників у Mentimeter, дослідження переваг навчальної відеокомунікації через сервіс Flipgrid, розробка чек-листів засобами сервісу Checklists.expert та ін.

Аналіз результатів формувального етапу педагогічного експерименту засвідчив, що в професійній підготовці майбутніх учителів початкової школи до організації дистанційного освітнього процесу відбулися суттєві зміни. Якщо до засвоєння змісту курсу студенти не орієнтувалися в понятійно-термінологічному апараті проблеми, відчували значні труднощі в прийнятті рішень у певних організаційних питаннях дистанційного навчання, то після опанування дисципліни вони могли впевнено будувати свою профресійну діяльність за декількома алгоритмами дій, були обізнані щодо правових і методичних основ організації діяльності учасників освітнього процесу в умовах функціонування поза межами освітньої установи. Як підсумок, кількість студентів експериментальної групи з високим рівнем досягнень з дисципліни «Дистанційна освіта в початковій школі» збільшилась на $33,95 \%$, у той час як в контрольній групі різниця склала лише 5,3\%. Зменшились показники низького рівня в експериментальній групі на 22,09\%, а в контрольній - на 9,77\%, що свідчить про ефективність змісту курсу.

Комплексність дисципліни забезпечила досягнення таких важливих результатів, як системні теоретичні знання щодо сутності дистанційного та змішаного навчання в початковій школі; уміння моделювати й організовувати дистанційний освітній процес у початковій школі, розробляти навчально-методичне забезпечення, фрормувати ключові та предметні компетентності здобувачів початкової освіти; досвід використання цифрових технологій для урізноманітнення 
освітнього процесу; здатність постійно вдосконалюватись особистісно та професійно, творчо використовувати перспективний педагогічний досвід вітчизняних та зарубіжних педагогів.

Висновки. Аналіз досвіду організації дистанційного освітнього процесу в початковій школі протягом останніх двох років дозволив визначити важливу проблему, яка суттєво впливає на його якість, а саме рівень готовності випускників закладів вищої освіти до професійної діяльності в умовах пандемії. Зміст вибіркової дисципліни «Дистанційна освіта в початковій школі» забезпечує фрормування в майбутніх учителів досвіду дій в умовах дистанційного освітнього процесу початкової школи, що забезпечує практико-орієнтований характер їх підготовки.

Зважаючи на швидкість розвитку цифрових технологій, дистанційне навчання буде відігравати велику роль у майбутньому. Тому вбачаємо перспективи подальших наукових пошуків у визначенні змісту підготовки майбутніх учителів початкової школи до виховної роботи в дистанційному режимі.

\section{Література}

Биков В., Лещенко М. Цифрова гуманістична педагогіка відкритої освіти. Теорія і практика управління соціальними системами: фрілософрія, психологія, педагогіка, соціологія. 2016. Вип. 4. С. 115-130.

Будник О. Підготовка вчителя до розвитку цифрової грамотності учнів Нової української школи. Освітні обрії. 2020. № 1 (50). С. 140-145.

Вишневський В. П., Гаркушенко О. М., Князєв С. І., Липницький Д. В., Чекіна В.Д. Цифровізація економіки України: трансформаційний потенціал: монографія / за ред. В. П. Вишневського та С. І. Князєва. Київ : Академперіодика, 2020. $188 \mathrm{c}$.

Дистанційне навчання: виклики, результати та перспективи. Порадник. 3 досвіду роботи освітян міста Києва: навч.-метод. посіб. / упоряд. : І. П. Воротникова, Н.В.Чайковська. Київ : Київський ун-т ім. Б. Грінченка, 2020. 456 c. URL: https://don.kyivcity.gov.ua/files/2020/8/19/90.pdf (дата звернення 21.10.2021).

Коваль Л. В. Європейський вектор стратегічних змін у професійній підготовці майбутніх учителів початкової школи. Педагогіка формування творчої особистості у вищій і загальноосвітній школах : зб. наук. пр. Запоріжжя : КПУ, 2021. Вип. 76. С. 158-161.

Кухаренко В. М., Бондаренко В. В. Екстрене дистанційне навчання В Україні : монографія / за ред. В. М. Кухаренка, В. В. Бондаренка. Харків : КП «Міська друкарня», 2020. 409 с.

Муковіз О. П. Основи дистанційного навчання у початковій освіті : навч.метод. посіб. Умань : Візаві, 2018. 128 с.

Організація дистанційного навчання в школі: метод. реком. / упор. І. Коберник, 3. Звиняцьківська.

URL : https://mon.gov.ua/storage/app/media/zagalna\%20serednya/metodichni\%20recomend azii/2020/metodichni\%20recomendazii-dustanciyna\%20osvita-2020.pdf (дата звернення 21.10.2021).

Спиваковский А. В., Петухова Л. Е., К Кравцов Г. М., Воропай Н. А., Коткова В. В. Новая дидактика: от субъект-субъектных - к трисубъектным отношениям : учеб. пособие / под ред. д-ра пед. наук, проф. А. В. Спиваковского. Херсон : Айлант, 2016. 276 с. 
Струтинська О. В., Умрик М. А. Сучасні освітні тренди в умовах розвитку цифрового суспільства. Інноваційна педагогіка. 2020. Вип. 26. С. 201-205.

Цифрова адженда України - 2020. Концептуальні засади. Київ : HiTech Office, 2016. 90 c. URL: https://ucci.org.ua/uploads/files/58e78ee3c3922.pdf (дата звернення 21.10.2021).

Blyznyuk T., Budnyk O., Kachak T. Boom in distance learning during the coronavirus pandemic: challenges and possibilities. Journal of Vasyl Stefanyk Precarpathian National University. 2021. Vol. 8, No. 1. pp. 90-98.

Nesterenko M. Implementation of scientific approaches to effective professional training of future informatics teachers in primary school under distance educational process. Education in the post-coronavirus world: the place of information and innovative technologies: monograph / Edited by Aleksander Ostenda, Oksana Dzhus. Monograph 41. Poland: Publishing House of Katowice School of Technology, 2020. 392 p. Pp. 65-71.

Sagan O., Nahrybelniy Ya., Nahrybeina I., Fediaieva V., Liba N., Kabelnikova N. Digital educational environment as a system-forming element of digital didactics. Revista Inclusiones. Vol. 7 (num Especial). 2020. Pp. 282-290.

Smyrnova-Trybulska E., Morze N., Kommers P., Zuziak W., Gladun M. Educational robots in primary school teachers' and students' opinion about stem education for young learners. Internet technologies and society. Melbourne, Australia: International Association for Development of the Information Society. 2016. December. Pp. 197-204.

\section{References}

By`kov V., Leshhenko M. (2016) Cy`frova gumanisty`chna pedagogika vidkry'toyi osvity` [Digital humanistic pedagogy of open education]. Teoriya i prakty 'ka upravlinnya social'ny'my' sy`stemamy`: filosofiya, psy`xologiya, pedagogika, sociologiya, 4, 115-130. [in Ukrainian].

Budny`k O. (2020) Pidgotovka vchy`telya do rozvy tku cy`frovoyi gramotnosti uchniv Novoyi ukrayins koyi shkoly [Professional training of teachers for the development of digital literacy of students of the New Ukrainian School]. Osvitni obriyi, 1(50), 140-145. [in Ukrainian].

Vy`shnevs`ky`j V.P., Garkushenko O.M., Knyazyev S.I., Ly`pny`cz`ky`j D.V., Chekina V.D. (2020) Cy`frovizaciya ekonomiky` Ukrayiny”: transformacijny j potencial [Digitization of Ukraine's economy: transformation potential]. Ky'yiv. [in Ukrainian].

Dy`stancijne navchannya: vy`kly`ky', rezul'taty` ta perspekty`vy'. Poradny`k. Z dosvidu roboty` osvityan mista Ky'yeva (2020) [Distance learning: challenges, results and prospects. Adviser. From the experience of educators of the city of Kyiv]. Ky yiv. [in Ukrainian].

Koval L.V. (2021) Yevropejs`ky’j vektor strategichny’x zmin u profesijnij pidgotovci majbutnix uchy teliv pochatkovoyi shkoly` [European vector of strategic changes in the training of future primary school teachers]. Pedagogika formuvannya tvorchoyi osoby`stosti u vy`shhij i zagal'noosvitnij shkolax, 184, 158-161. [in Ukrainian].

Kuxarenko V.M., Bondarenko V.V. (2020) Ekstrene dy`stancijne navchannya v Ukrayini [Emergency distance learning in Ukraine]. Xarkiv. [in Ukrainian].

Mukoviz O.P. (2018) Osnovy dy’stancijnogo navchannya u pochatkovij osviti [Fundamentals of distance learning in primary education]. Uman. 128. [in Ukrainian].

Organizaciya dy`stancijnogo navchannya v shkoli: metod. rekom. (2020) [Organization of distance learning at school]. [Electronic resource]. Available at: https://mon.gov.ua/storage/app/media/zagalna\%20serednya/metodichni\%20recomend azii/2020/metodichni\%20recomendazii-dustanciyna\%20osvita-2020.pdf. [in Ukrainian]. 
Spy`vakovsky j A.V., Petuxova L.E., Kravczov G.M., Voropaj N.A., Kotkova V.V. (2016) Novaya dy dakty`ka: ot subъekt-subъektnыx - k try`subъektnыm otnosheny yam [New didactics: from subject-subject - to trisubject relations]. Herson. 276 s. [in Russian].

Struty`ns`ka O.V., Umry`k M.A. (2020) Suchasni osvitni trendy` v umovax rozvy tku cy'frovogo suspil'stva [Modern educational trends in the development of digital society]. Innovacijna pedagogika. 26. 201-205. [in Ukrainian].

Cy’frova adzhenda Ukrayiny` - 2020. Konceptual'ni zasady` (2016) [Digital Agenda of Ukraine - 2020. Conceptual principles]. Ky yiv. $90 \mathrm{~s}$. [Electronic resource]. Available at: https://ucci.org.ua/uploads/files/58e78ee3c3922.pdf. [in Ukrainian].

Blyznyuk T., Budnyk O., Kachak T. (2021) Boom in distance learning during the coronavirus pandemic: challenges and possibilities. Journal of Vasyl Stefanyk Precarpathian National University. Vol. 8. 90-98. [in English].

Nesterenko M. (2020) Implementation of scientific approaches to effective professional training of future informatics teachers in primary school under distance educational process. Education in the post-coronavirus world: the place of information and innovative technologies. Poland: Katowice. 392 p. PP. 65-71. [in English].

Sagan O., Nahrybelniy Ya., Nahrybeina I., Fediaieva V., Liba N., Kabelnikova N. (2020) Digital educational environment as a system-forming element of digital didactics. Revista Inclusiones. Vol. 7. Pp. 282-290. [in English].

Smyrnova-Trybulska E., Morze N., Kommers P., Zuziak W., Gladun M. (2016) Educational robots in primary school teachers' and students' opinion about stem education for young learners. Internet technologies and society. Melbourne, Australia. pp. 197-204. [in English].

\section{АНОТАЦІЯ}

У статті проаналізовано причини та результати першого досвіду масової роботи освітніх закладів України в дистанційному режимі, які засвідчили, що в цілому вдалося змінити й адаптувати ї середовище для його повноцінного фуункціонування. Визначено перспективність розвитку дистанційних технологій навчання, які забезпечують доступ людей до освіти без обмежень за віком, статтю, соціальним статусом, станом здоров'я та в умовах надзвичайних ситуацій, що підвищує мобільність суспільства.

Виявлено, що особливої уваги потребує проблема профресійної підготовки майбутніх учителів до організації дистанційного освітнього процесу в початковій школі, оскільки для дітей молодшого шкільного віку характерним $\epsilon$ низький рівень самостійності навчально-пізнавальної діяльності, слабка довільність уваги, висока потреба в особистому контакті з учителем. Це зумовлює специфріку діяльності педагога.

Презентовано короткий зміст i експериментально доведено ефрективність вибіркового освітнього компонента "Дистанційна освіта в початковій школі», який спрямовано на фрормування профресійної компетентності майбутніх учителів, що забезпечує готовність до реалізації освітнього процесу в початковій школі у форматі дистанційного або змішаного навчання. Студенти мають можливість дослідити сутність дистанційної фрорми навчання в початковій школі; зрозуміти специфріку комунікації вчителя з учнями, батьками, адміністрацією під час дистанційного навчання, роботи з дітьми з особливими освітніми потребами в таких умовах; вивчити методичні рекомендації з організації онлайн занять; визначити технічні, ергономічні й етичні критерії якісної відеоконференції; оволодіти досвідом роботи з різними сервісами для організації відеозв язку; опанувати загальні принципи організації дистанційного освітнього процесу за допомогою 
Goggle Clasroom; ознайомитися з якісними украӥномовними відеоресурсами для візуалізації навчального матеріалу уроку, сервісами для проведення онлайн тестувань учнів, зручностями інтерактивних онлайн дошок.

Ключові слова: підготовка майбутніх учителів початкової школи, дистанційний освітній процес у початковій школі, цифровізація суспільства, цифрова педагогіка, технології реалізації дистанційного навчання, вибіркова дисципліна. 